\title{
Understanding the Knowledge and Data Landscape of Climate Change Impacts and Adaptation in the Chesapeake Bay Region: A Systematic Review
}

\author{
Jose Daniel Teodoro ${ }^{1, *}$ and Bruce Nairn ${ }^{2}$ \\ 1 Department of Geographical Sciences, University of Maryland, College Park, MD 20742, USA \\ 2 Department of Emergency and Disaster Management, Georgetown University, Washington, DC 20057, USA; \\ nairnbruce127@gmail.com \\ * Correspondence: teodoro@umd.edu; Tel.: +31-6-4088-2035
}

Received: 30 March 2020; Accepted: 15 April 2020; Published: 17 April 2020

\begin{abstract}
Climate change is increasingly threatening coastal communities around the world. This article reviews the literature on climate change impacts and adaptation in the Chesapeake Bay region (USA). We reviewed both climate impacts and adaptation literature $(\mathrm{n}=283)$ published in the period 2007-2018 to answer the questions: (i) how are indicators of climate impacts measured and reported by different types of authors (e.g., scientists, government, and NGOs), document types (e.g., academic articles or reports), and geographic focus (e.g., State, region, county, or municipal level)? (ii) what are the current approaches for measuring the most pressing climate impacts in the Chesapeake Bay? We found that scientists produce the most amount of data but are increasingly shifting towards engaging with practitioners through reports and online resources. Most indicators focus on the Chesapeake Bay scale, but data is most needed at the local level where adaptive policies are implemented. Our analysis shows emerging approaches to monitoring climate hazards and areas where synergies between types of authors are likely to increase resilience in the 21st century. This review expands the understanding of the information network in the Chesapeake Bay and explores the institutional landscape of stakeholders involved in the production and consumption of environmental and social change data. The analysis and insights of this review may be extended to similar regions around the planet experiencing or anticipating similar climate hazards to the Chesapeake Bay.
\end{abstract}

Keywords: knowledge; Maryland; climate indicators; qualitative analysis; climate governance

\section{Introduction}

Anthropogenic climate change is a threat to the livelihood of humans and the sustainability of our civilization into the future [1]. Climate-related risks to human and natural systems have already been observed, and changes in the ocean and land ecosystems and the services they provide have already changed due to global warming [2]. Climate changes affect different regions of the planet in different ways, which demand national and sub-national governments to design adaptation and mitigation actions to address the relevant concerns of their society and geography [3,4]. In the United States, climate change is predicted to have cascading effects in the social, economic, and ecological systems, and it is estimated that climate-related impacts on the U.S. economy may results in a $10 \%$ shrinkage by the year 2100 [5]. Even within the United States, climate change will have varying impacts; for example, coastal areas are particularly susceptible to the effects of sea-level rise (SLR) and arid areas of the southwest prone to drought and wildfires [1]. Developing adaptation policies and strategies based on scientific and local knowledge mixed with the use of modern technologies have the 
potential to reduce the risk of climate change to human lives and natural ecosystems and strengthen our economic and social systems in anticipation to projected impacts [6]. However, the processes that enable successful adaptation to climate change, those that support democratic stakeholder participation and consensus-building, are yet to take hold of mainstream local environmental politics.

Adapting to the climate's imminent threats is still an ongoing challenge and largely a geographic-specific issue. The multi-scale governance-the dynamic vertical structure of communication and power that may scale from a municipal boundary to the government of a state or nation —of a place that is vulnerable to climate impacts must transform itself into an efficient system. Scientific literature suggests that the adaptive capacity of vulnerable populations, cities, and counties largely depends on governance structure $[7,8]$, local and scientific knowledge integration $[9,10]$, and establishing strong social networks [11]. Indeed, there has been an increase in the scientific and management information on climate change in the last decade but progress in the adaptation space remains a challenge for many communities and local governments [12]. The vastness of information often leaves stakeholders overwhelmed and unsure how to understand their community's resilience. Thus, this report reviews the literature on climate adaptation indicators from 2007-2018 with a geographic focus of the Chesapeake Bay (Maryland) in the United States.

This article focuses on the Chesapeake Bay because it is a region already experiencing major climate-related impacts of sea-level rise, more hurricanes and tropical storms, and is projected to get worse throughout the 21st century. Adequately responding to climate hazards and increasing local resilience requires the active participation of stakeholders across multiple levels of the state of Maryland's government [13] and engagement of the local, scientific, and non-profit communities. Adaptation is more challenging when the institutional landscape of actors is made up of many universities, research institutes, civil organizations, government agencies, and community organizations. Thus, an important challenge in adaptation science is the compilation and synthesis of all available information, distinguishing the nuanced differences between author types, document types, and geographic scale.

Following the conclusions by the Maryland Commission on Climate Change (MCCC), we agree there is a need for a cohesive research agenda for the state of Maryland and the Chesapeake Bay that communicates the science needed to support state and local decision-making [14]. We reviewed the available literature by multiple author types (local, county, state government, non-governmental research and outreach organizations, as well as scientific journal publications) in order to contribute to the understanding of climate adaptation science and practice to this date. We do so by asking the following questions: (i) how are indicators of climate impacts measured and reported by different types of authors, document types, and geographic focus? (ii) what are the current approaches for measuring the most pressing climate impacts in Maryland and the Chesapeake Bay? We close with research and practitioner-focus recommendations on emerging indicators of climate adaptation and outlook. The findings and conclusions of this review article are meant to advance the understanding of climate adaptation and resilience in the State of Maryland and add to the development of a holistic framework for climate resilience measurement across multiple regions.

\section{Materials and Methods}

A qualitative review analysis was employed on scientific and non-academic literature to evaluate existing data on the use of indicators and metrics to track the trends of climate change impacts within the state of Maryland. This section describes the study area, the methodology used to make the final determination of the article sample, data collection, and the qualitative approach used to analyze and synthesize the data.

\subsection{Climate Change in Maryland, USA}

Coastal areas in the United States are at risk of drought and flooding, shoreline erosion, salt-water intrusion, and other climate-related hazards [15]. The Chesapeake Bay is the largest estuary in 
the United States and one of the most diverse. Maryland's over 4000-miles of shoreline, and its network of tidal rivers and the Atlantic coast, makes the state particularly susceptible to flooding and erosion brought on by tides, storms, and increasingly SLR [16]. These climate hazards are already impacting coastal communities in Maryland and are expected to worsen [4,17-19]. Nuisance flooding (also referred to as sunny-day flooding or high tide flooding) is projected to increase in frequency due to global SLR, and by 2100 high tide flooding will occur 'every other day' or more often [20]. Scenarios for $\mathrm{CO}_{2}$ emissions suggest the region is likely to experience significant changes in climatic conditions in the 21st century, including increasing $\mathrm{CO} 2$ concentrations by 50 to 160 percent, increasing water temperature by 2 to $6^{\circ} \mathrm{C}$, and fluctuating precipitation patterns [16].

Maryland has historically been at the forefront of states acting to address drivers and consequences of climate change. The policy record of Maryland shows that the state has directed agencies at all levels of government, academic, and private institutions to understand and respond to environmental conditions like sea-level rise, clean air, and land conservation [14]. In 2013, Maryland passed into state law the Maryland Commission on Climate Change (MCCC), initially formed in 2007 by Executive Decree (01.01.2007.07) to provide objective legislative advice and research support. The creation of the MCCC signaled the level of concern and urgency felt by Marylanders, many who have inhabited the Chesapeake Bay for many generations and who increasingly consider climate change among the major threats to the state [21]. However, the growing dangers of anthropogenic climate change to the state has fueled a surge of efforts to combat climate hazards with robust science and policies that incorporate the participation of multiple stakeholders [17].

We chose to focus on the state of Maryland because of its historical track record of adopting policy and promoting collaborations to combat climate change, its wealth of information on climate-related hazards, and because it exemplifies specific challenges faced by large coastal regions impacted by coastal-specific climate hazards (e.g., SLR, coastal ecosystem changes, and stormwater management in a mostly agricultural watershed).

\subsection{Document Selection}

We collected reports and articles from scientific and non-academic literature. Scientific articles published in peer-reviewed journals were collected from the Web of Science using the following code: "TS = (("Maryland" OR "Chesapeake Bay") AND (Climat* OR Indicator*) AND (Resilience OR Hazard OR Exposure OR Impact OR Susceptibility OR Adaptation OR Coping OR Capacity OR Mitigation))," and the search was restricted to include only articles published between 2007-2018; the period since the creation of the MCCC. Non-academic literature was searched using the same keywords in the Google search engine, following the approach by Godin et al. [22]. The title, abstract, and keywords for each search result-scientific and non-academic literature-were scanned for geographic and topic relevance following the procedure described in Supplementary Material Document S1. From the initial sample, excluding duplicates, 717 documents were screened full-text to determine if they contained data and indicators. A final sample of 283 articles was reviewed and included for qualitative coding (Figure 1).

\subsection{Qualitative Coding and Analysis}

Drawing from the methodology of Saldaña [23], we identified the broader trends and themes in the literature concerning the aspects of climate hazards and adaptation efforts in Maryland. Using the qualitative coding software NVivo 12.3 [24], each document was first coded for its source information (the type of author, type of document, and geographic focus). Then every instance in a document where an indicator or dataset was identified was coded based on six aspects: (1) what aspect of climate change is being measured, (2) the geographic scale of that indicator, (3) type of information included, (4) type of indicator (i.e., lagging, coincident, or leading), (5) which aspect of the resilience framework it addresses, and (6) if it pertained to social characteristics or demographics. Additionally, optional codes were used to capture the instances where a clear methodology for an indicator was 
provided. In sum, a total of 139 unique thematic codes made the coding schema applied in this review (Supplementary Material Document S2).

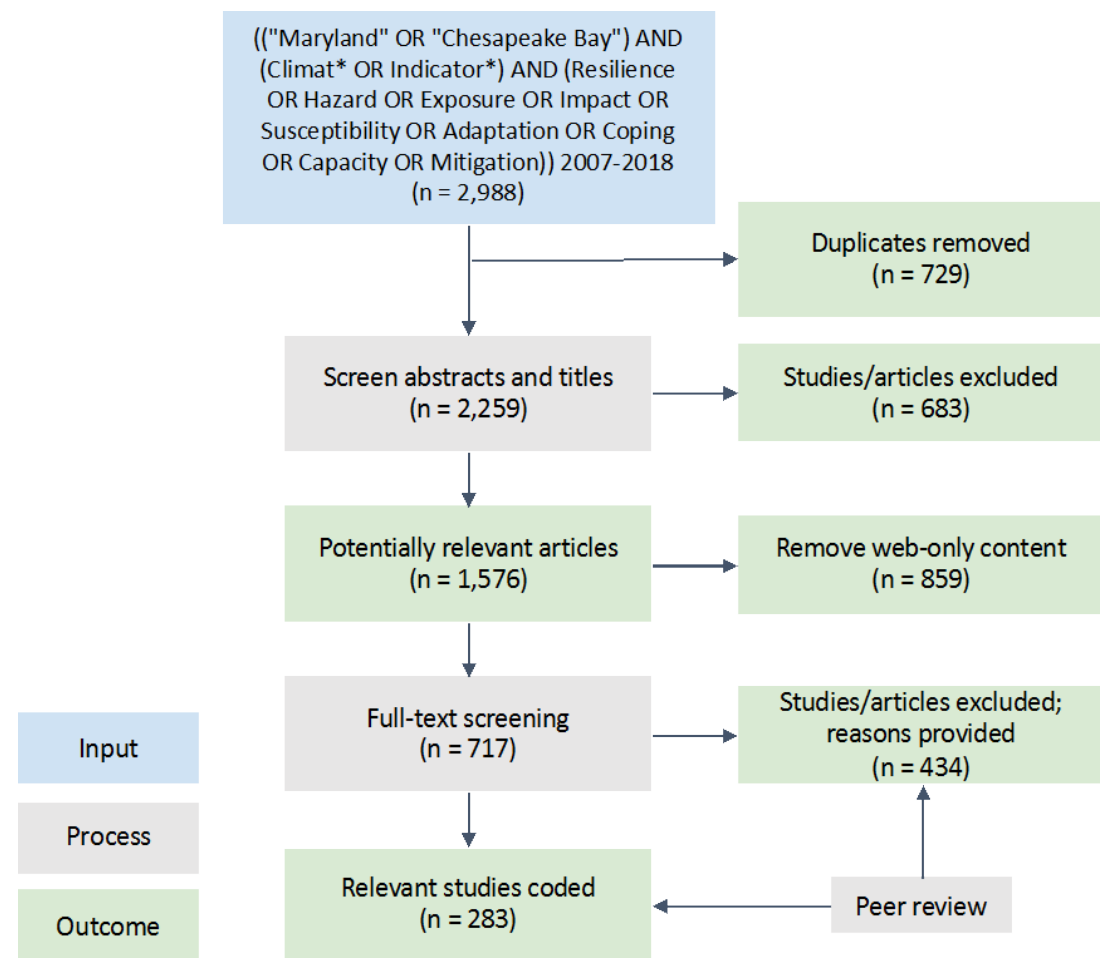

Figure 1. Document selection process for systematic review.

After all included documents were coded, we carried out a qualitative analysis following the methodology developed by Petticrew and Roberts [25], which follows three steps: First, all documents were organized into cases based on the type of author, geographic focus, and whether the document was a scientific or non-academic publication. Second, we analyzed the information found within each case to help identify emerging themes within each case (e.g., the focus on climate adaptation by different types of authors). The third step involved analyzing the information across cases to understand the cross-cutting themes throughout the document database. The combined process provides a comprehensive qualitative analysis of the literature on climate change resilience and adaptation in Maryland.

\section{Results}

\subsection{Dataset Overview}

The final sample of documents that met the inclusion criteria resulted in 283 files. Visualized using a Sankey diagram, it is clear that several large clusters are present (Figure 2). In terms of geographic focus, the Chesapeake Bay is the geographic focus of about one-third of the documents. Of these, almost all are written by academic scientists, with about one-third of the Chesapeake Bay documents being scientific articles and another third being reports. As a group, the output of academic scientists is overwhelmingly focused on the Chesapeake Bay.

About one-third of the documents focus on the state level. These are predominantly written in report form by state and national governments. The remaining third of the documents are spread among the municipal, country, regional, national, and global levels, with the majority of documents addressing the municipal and county levels. These are almost all in report form and authored mostly by county and municipal governments and NGOs. 
(a)

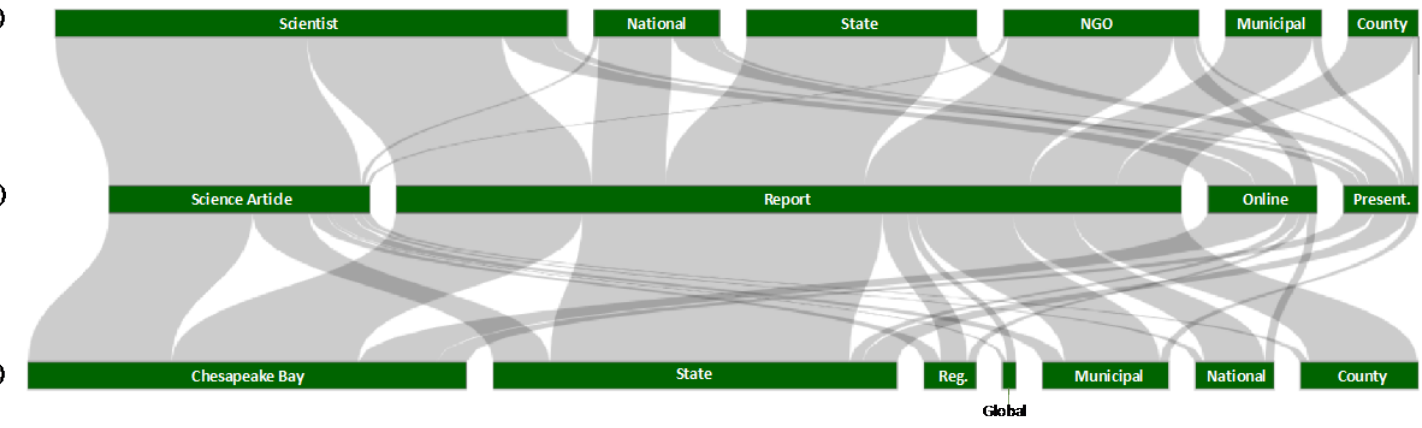

Figure 2. Descriptive distribution of: (a) type of author, (b) type of document (i.e., Science article, report, presentation, or online resource), and (c) geographic focus of the document.

The distribution of author types within our sample and the means of communicating information to the wider public show the complex institutional landscape of climate adaptation in the Chesapeake Bay. The largest author type within our sample are scientists (42\%), who author almost the same number of scientific articles and non-academic reports. When looking at document types, the dominant form of climate adaptation and resilience literature in Maryland are reports, covering $64 \%$ of the sample. It may be worth mentioning that almost all documents authored by County-level authors were in report form and the remaining sliver were presentations.

When exploring our sample based on the year of publication, the amount of the documents shows an upward trend with a larger number of documents being published in the latter part of the sampling period (Figure 3). Most of the increase after 2014 originates in academic articles about the Chesapeake Bay. An outlier in the trend is the year 2008, in which a large number of documents were published. Most of the reports were authored by the state government and scientists with a state-wide geographic focus. This increase may be explained by the creation of the Maryland Commission on Climate Change in 2007, which marked the beginning of scientific and political attention to climate change impacts in Maryland and the Chesapeake Bay.

\subsection{Focus on Indicators and Data}

Within every document we found data, metrics, or indicators that captured quantitative information about climate change impacts and responses. There are well known reviews of the climate impacts affecting the Chesapeake Bay [16] and the United States [26]. Therefore, we do not claim this section provides new information in general. However, the contribution of our review in this section should be considered with a lens of available quantitative measures/metrics. These data may be used in the development of better climate resilience and adaptation indicator systems. It is not always possible to collect data on climate hazards and impacts that are qualitatively well known to the local communities and resource managers in the Chesapeake Bay. An example of this is the finding that County-authored documents often described the vulnerability and risk of increasing river discharge flows, but it was the scientific-authored documents that provide quantitative data and analysis of those impacts. Therefore, in this section we elaborate on the information of climate change and impacts within our sample limited to those that met the substantive data/indicators criteria.

Communities around the Chesapeake Bay already experience tangible impacts to their infrastructure, social life, and economy due to climate hazards [17]. The low-lying coastal geography of Maryland makes the region particularly vulnerable to mean sea-level rise (SLR) $[20,27,28]$. Moreover, current and projected changes in precipitation patterns in Maryland and the Chesapeake Bay watershed are expected to add pressure to stormwater systems and increase agricultural runoff [29-31]. In turn, changes in the water quality and temperature in the bay pose considerable risks to the health of marine ecosystems, which are likely to have adverse economic and social impacts on coastal communities [32-35]. The economic underline of many climate impact data is not surprising, given that the Chesapeake Bay has long been an economically productive source of income; fish, shellfish, and 
oysters provided the State of Maryland with a \$63 million in 2013 [14]. Another focus on climate impact data, albeit not very prominent within our sample, is the association between climate change (e.g., rising temperature and more frequent hurricanes/storms) and aspects of human health (e.g., hospitalization rates and incidence of water-borne diseases). Taken together, the concert of interconnected impacts in the Chesapeake Bay pose significant challenges to researchers and practitioners in developing adequate responses to climate change.

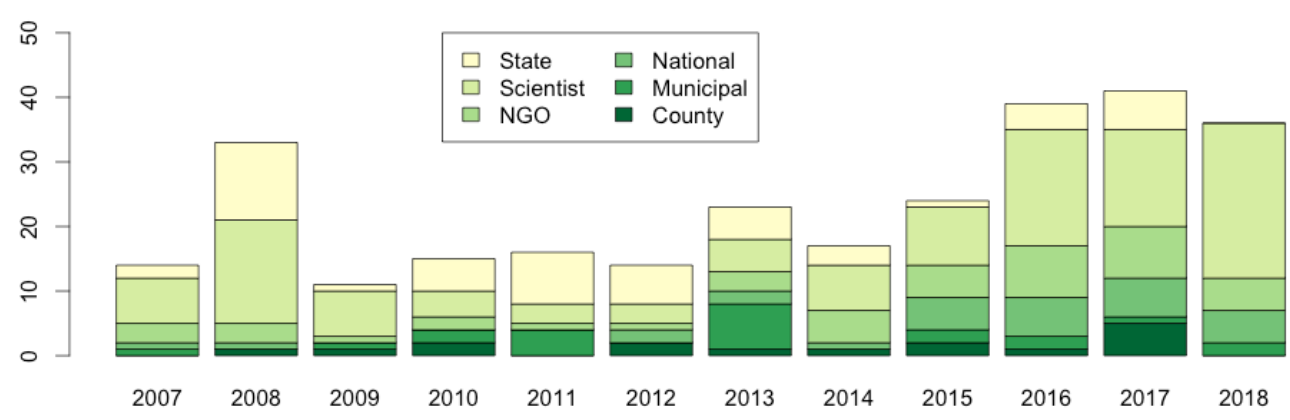

(a) Author Type by Year of publication

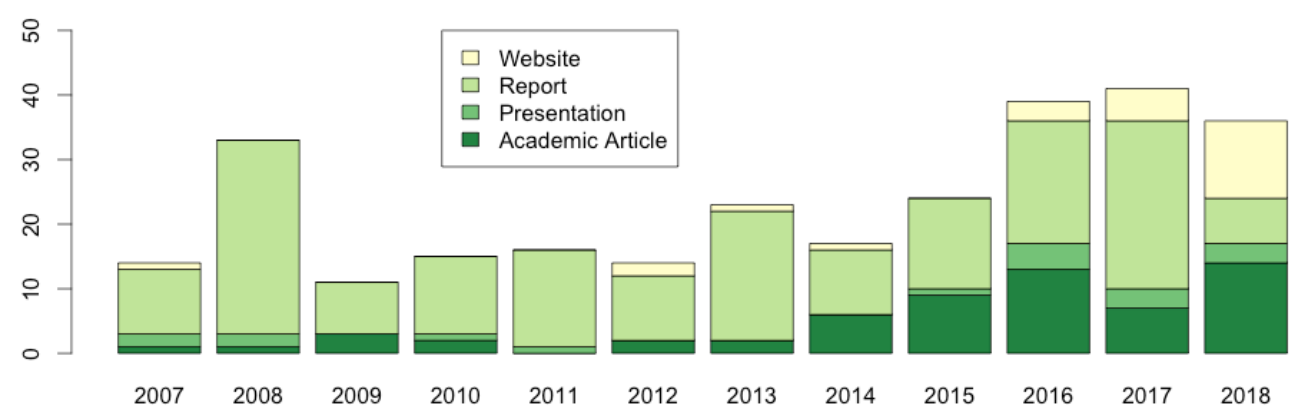

(b) Document Type by Year of publication

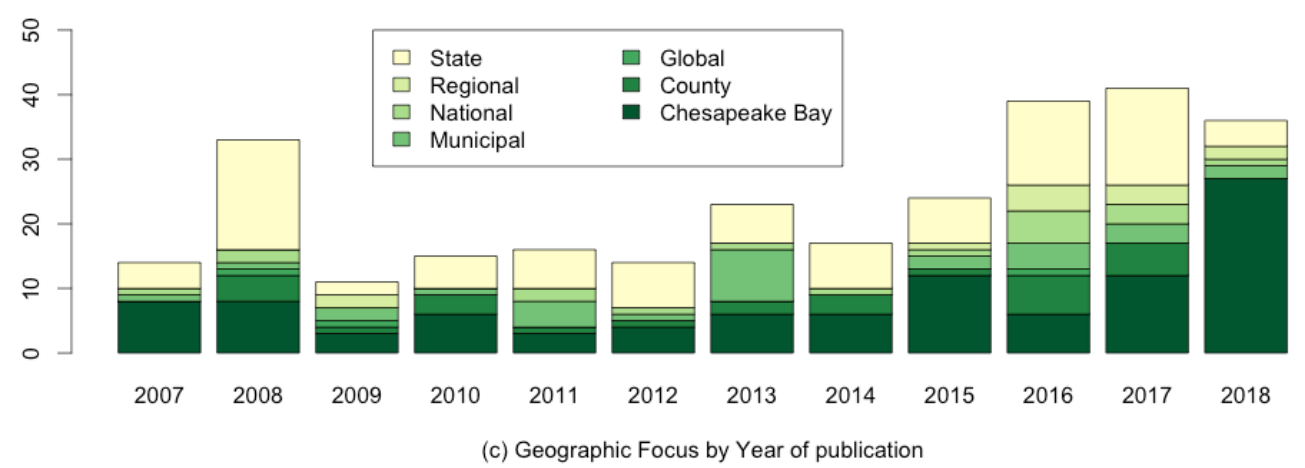

Figure 3. Year of publication of sampled documents by (a) type of author, (b) type of document, and (c) geographic focus of document.

\subsubsection{Sea-Level Rise (Aquatic-Type Indicators)}

Indicators focused on aquatic climate impacts are found in most documents (Figure 4). Aquatic indicators include coastal and river flooding, marine species health and abundance, SLR, stream flows, water quality among others. In the Chesapeake Bay, SLR and related impacts are the dominant theme in the Aquatic type datasets and indicators. SLR in the Chesapeake Bay is projected to 
reach between 2-6 ft. in this century, which is higher than the global mean SLR [14,20,28]. According to the Maryland Commission on Climate Change [27], even the most optimistic SLR scenarios are projected to have considerable impacts on the Bay communities. Indicators and data within the Aquatic theme, specifically SLR and coastal/river flooding indicators were dominant across all types of authors (i.e., government, NGO, and academic authors), and at all geographic levels (i.e., municipal, county, state). Most of these indicators were found in reports.

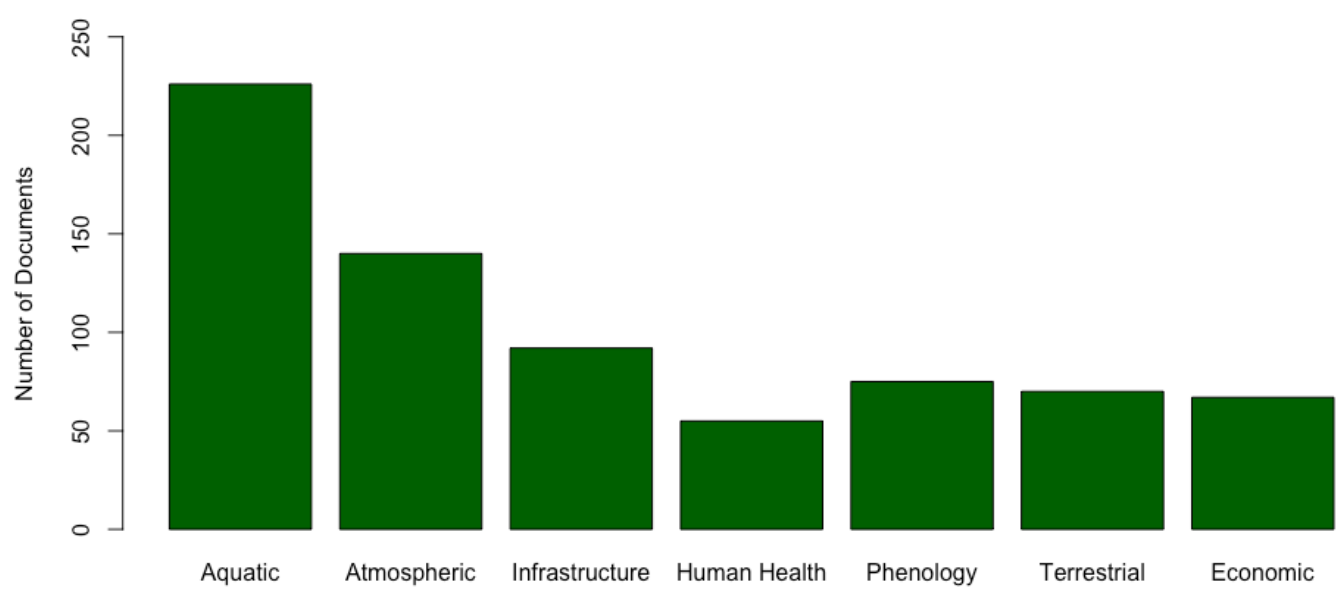

Figure 4. Number of documents that contained different climate change impact indicators.

When looking at the format of SLR data and indicators available, many documents focus on the economic effects SLR will have on the future based on different climate projections [36-39]. Flooding of coastal areas and floodplains, either by increased precipitation $[40,41]$, chronic sea-level rise $[17,27,28]$, or storm surges [42], will damage private and public infrastructure and cause large economic loss. The risk and impacts of SLR are commonly measured with detailed flood projection maps based on different climate scenarios, and a spatial assessment of the number of buildings and infrastructure that would be affected $[36,37,42]$. Methods employed to measure the projected spatial risk of SLR include several of the Federal Emergency Management Administration (FEMA)'s flooding and hazard assessment tools like HAZUS-MH. These types of analyses are useful for identifying and prioritizing the most vulnerable areas to SLR and flooding from storms and hurricanes across multiple locations and estimating the cost of damage to infrastructure [43-45]. As a result, increasing flood protection and adapting building codes in response to projected SLR-driven impacts in 2050 and 2100 are relevant considerations for some coastal counties in Maryland [36,46-48]. Improving the resolution of these map-based analyses will likely empower local-level resource managers and community members to take, and measure, adaptive actions.

The Chesapeake Bay is a large estuarine system with wetlands and marshlands. As such, several documents provide in-depth analyses of the effects SLR is projected to have on coastal habitats [32,49-53], some of which are projected to lose between $58 \%$ to $69 \%$ of their habitat by 2100 [32]. Even though major changes in the composition of coastal ecosystems can be expected, the implications of those changes for humans or marine life are not yet fully understood [54]. Understanding the changes of coastal habitats in relation to how they affect humans can facilitate the development of adaptive strategies that enable the adaptive potential of those habitats [54,55].

\subsubsection{Precipitation and Nutrient Loading in Watershed Hydrology}

Predictions of precipitation changes in the Chesapeake Bay watershed in this century are less understood than temperature projections [16]. However, data found in the reviewed documents show an increase in precipitation compared to current conditions [41,56,57]. Renkenberger et al. [41] estimate changes in precipitation to increase between $25 \%-30 \%$ by the end of the century. Other sources show more conservative predictions: Hawkins [57] predicts a smaller increase of 5.2\% to $15.2 \%$, 
and Pyke et al. [16] predicted 3\% to $8 \%$. In general, precipitation is likely to increase during winter (less as snow) and decrease during summer and fall [57,58]. In Maryland, and the Chesapeake Bay, increasing precipitation contributes to inland flooding [42], higher non-point source sediment and nutrient pollution into the Chesapeake Bay watershed [30,41,56], higher soil erosion [59], impacts on agricultural yields [60,61], increases pressure on rain and wastewater management systems [16,31], increases in the risk of dam failures [62], and contributes to growth of water-borne diseases [60,63]. Moreover, the seasonal variability of projected precipitation may increase droughts in the summer months [61].

When comparing data between scientific journal publications and non-academic reports, particular distinctions emerge. Hydrological models, like the Soil Water Assessment Tool (SWAT), is more common in scientific literature $[30,41,56,64]$. In contrast, non-academic publications from government, NGOs, or research institutions, are less specific on the future impacts of precipitation changes but they recognize the potential vulnerabilities and emphasize resilience-building approaches $[16,60,61]$.

Some scientific studies show an association between increasing precipitation and human health $[63,65-68]$. Soneja et al. $[63,65]$ studies the relationship between changes in precipitation and temperature and increased risk of hospitalization for asthma and water-borne diseases. They show that an increase in the frequency of extreme heat and precipitation events will have a significant impact on public health, especially asthma during summertime extreme precipitation events. It is essential to mention that this association is rare within our sample, and more research in this subject is needed to develop adaptive policies.

The predicted increases in precipitation pose serious management challenges to control nutrient pollution in the Bay and achieve the goals of the Chesapeake Bay Watershed Agreement [69]. Among our sample of documents, data suggests that the water quality in the Bay will undergo biochemical changes that will affect aquatic life. Most notably, the exacerbation of hypoxia-zones of low levels of oxygen that cannot support fish—will have detrimental effects on marine organisms and ecosystems [60,70-73]. Although seasonal hypoxia is a natural feature of estuaries, indicators show that these "dead zones" are becoming more frequent in many parts of the world due to human impact on the ecosystem $[16,74]$. Moreover, changes in the water quality and chemistry, as well as higher water temperatures $[33,75,76]$ and acidification [35], pose serious threats to aquatic life. These changes can affect aquatic life that is economically and ecologically important to the Chesapeake Bay; such as the blue crab [33,75] softshell clam [34,35], striped bass [77], algae [60,73], and marine grasses [77]. The Eco Health Report Card has been a consistent indicator of the Chesapeake Bay's water quality since 1986 [77]. In 2017, the latest reporting period at the time of this writing, the Eco Health Score was showing a trend of slow improvement. With increasing precipitation and streamflow, it is more likely that maintaining the improvement trend will become harder through this century, and perhaps impossible without aggressive nutrient and pollution reduction management strategies [72].

\subsection{Emerging Themes in Climate Change Adaptation}

Adaptation researchers and professionals may find available studies and reports on data on the projected impacts of more precipitation in the Bay. Conceptually, nothing new is provided by this knowledge. However, societies tend to measure things that matter to them [78]. In this case, available data and indicators on aspects of precipitation and their relationship with agricultural productivity, flooding, and water quality are central to increasing resilience. Certainly, more attention is needed on measuring aspects that reduce risk and increase resilience and incorporate those aspects in existing restoration and management efforts. On a qualitative note, multiple types of authors in our sample recognize that there is still much to be done in developing climate adaptation indicators and metrics that can be applied across the Chesapeake Bay watershed in a coordinated fashion to allow for timely implementation of adaptation strategies. The following adaptation themes refer to aspects the authors found to be significant in the development of holistic adaptation measures in the Chesapeake Bay. 


\subsubsection{Adapting to Sea-Level Rise}

Responding and adapting to SLR is a multi-faceted problem. First, improving the quality of data on SLR by upgrading the network of water sensors and real-time flood data will help to improve the predictions of street-level flooding [79]. The development of new datasets can and will facilitate the identification of flood risk areas in coastal communities and support the selection of priority shoreline areas for conservation and/or restoration. Moreover, collaborative decision-driven scientific tools have the potential to support the design of targeted adaptation strategies with known risk-reduction potential [80,81].

Developing and deploying the capabilities to identify shoreline areas of significant value and risk-reduction potential becomes relevant at the local level, where county and municipal governments dictate the land-use zoning codes. Empowering county and local-level managers and conservation professionals with tools to identify and monitor coastal habitat changes in real time will likely improve conservation and restoration efforts at the local level. At the state level, managing agencies can facilitate investment for land acquisition programs. In areas where inland migration of wetlands is difficult or impossible, other adaptation options, like green/blue infrastructure, have already been employed. For example, adding sediment to marshes, building oyster reefs, and living shorelines [82] have positive, albeit limited, benefits [83]. It may also be useful to promote the evaluation of uncommon adaptation measures and practices [84].

\subsubsection{Adapting to Increases in Precipitation}

Overall, the focus of adaptation to projected increases in precipitation relates to (i) the ability to improve our estimates of precipitation patterns into the future and (ii) the ability to upgrade stormwater management systems to meet the projected increase in precipitation. Adapting to precipitation changes will likely reduce flooding, ensure urban water quality, and control and reduce the associated runoff and nutrient loading into the Chesapeake Bay. Many documents reviewed in this report discuss the role of stormwater management as an adaptation focus in the wake of a projected increase of precipitation $[16,29,31]$. The stormwater infrastructure that is not intended to handle increased amounts of precipitation will have an increased likelihood of failure [17]. Communicating the limitations and vulnerabilities of water management systems to local governments will likely encourage the necessary upgrades given the substantial power local government has over stormwater management systems [31,85].

Impervious cover due to increasing urbanization prevents stormwater from infiltrating into the soil [29]. Therefore, employing green infrastructure and reducing impervious cover in flood-prone areas will increase the ground's capacity to absorb heavy precipitation [86]. Policy changes that encourage resilient building codes and practices are likely to reduce risk, as well as direct new development and investment to less flood-prone areas [17]. Adaptation-focused documents recommend increasing freeboard standards, the required elevation of the first floors of structures, to account for future SLR and change from a 100-year flood plain management strategy to a 500-year flood plain management strategy $[17,79]$. Upgrading zoning policies in floodplains to incorporate climate risks can both protect existing buildings and strengthen new and substantially improved buildings [86] (p. 204).

The predicted increase in precipitation in Maryland will result in an increase in agricultural runoff [59,64], which is likely to forestall progress by management actions without redoubled efforts [73]. As such, expanding the adoption of best management practices (BMPs) in riparian zones to minimize agricultural runoff, sediment transport, and nutrient loading will become increasingly necessary to address the impacts of climate change related to Bay's water quality. However, it is important for local managers to be able to identify the effectiveness of BMPs. It is recommended that BMPs effectiveness be measured by their GHG-reduction potential; as some research has shown [87]. Measuring the performance of BMPs in removing pollutants at different climate scenarios remains an ongoing challenge [29]. In the Chesapeake Bay, BMPs are implemented through watershed implementation 
plans (WIPs), defined by states and districts to ensure the water standard is not compromised. Thus, facilitating knowledge on BMP effectiveness into WIPs would likely accelerate the adoption rates.

\subsubsection{Stakeholder Participation}

A growing number of documents recognize and recommend the use of collaborative approaches in managing climate adaptation in social-ecological systems [12,16,85]. Planning for adaptation to SLR and other climate hazard requires regional partnerships and collaborative strategies, especially when climate and environmental hazards transcend municipal and county boundaries [79]. Climate adaptation is an interdisciplinary effort that requires the involvement of actors in social, economic, and environmental aspects of a community and region that harness knowledge that is pertinent to effective adaptation [16]. Measuring the extent to which stakeholder participation delivers measurable improvement and risk-reduction remains a challenge. However, the benefits of collaboration include the ability to create and harmonize data on climate change (e.g., SLR impacts), as it would be difficult for individual communities to collect the data and expertise necessary to address their climate vulnerabilities comprehensively.

\subsubsection{Perceptions as Measuring Tools}

Finally, a small but distinguishable number of documents focused on measuring perceptions from the public and adaptation professionals related to climate change and impacts. These studies and reports capture different types of perceptions from different types of respondents in different geographic locations. A unifying factor between them is their emphasis on the role perceptions may play in effective coastal climate adaptation planning, implementation, and monitoring. Many documents focused on studying perceptions of risk (i.e., 'feeling at risk of climate impacts') and investigated different variables that may be associated with increasing/reducing risk perceptions among stakeholders [88,89]. Perceptions of climate change may relate to the level of knowledge about climate change, the degree of trust in the responsible agencies, and/or the proximity to climate hazards. Perceptions can function as proxy measures of knowledge and awareness people have about aspects of climate change impacts and adaptation, which may help identify communication gaps among stakeholders [88,90]. Improving communication between administrators and local residents may greatly increase the effective implementation of adaptation policies. Akerlof et al. [91] showed that most residents were uncertain when SLR was going to significantly impact the county. In a survey of residents of Baltimore City and Prince George's County (MD), residents reported a low level of understanding of the climate impacts and their scientific projections [92]. Having limited knowledge of the facts of climate change has been linked to having a lower perception of risk of climate impacts [92]. Akerlof et al., [91] showed how information-driven collaborative events could have a positive effect on increasing people's awareness of climate risks while aligning their expectations of climate change to that of scientific knowledge. These studies show that such information may have a significant influence on the formation of individual perceptions and public opinion [93,94]; information that may be helpful in climate change adaptation efforts.

\subsection{Limitations}

Our review is not without its limitations. First, the impacts discussed in this review are the most dominant and urgent aspects of climate change in the Chesapeake Bay, but they are not the only ones. By accounting for the data/indicators that currently are predominant in the literature, we may have neglected important, yet covert, aspects of the social-ecological system that may play silent roles in exacerbating or constraining climate impacts. Second, our review lightly touches on the relation between climate change and human health, which is a subject of interest particularly to state and county governments. Even though we found inconclusive information on this subject we recognize that others have done more focused reviews on this [95]. Finally, we recognize that the lengthy process of coding data on the sampled documents is performed by humans who may commit unintended 
mistakes. To reduce human error, we employed extensive quality control processes, but it is impossible to rule out mis-coding as a possibility.

\subsection{Practical Implications}

This review article is intended to provide wide-reaching practical implications for tracking climate change impacts and adaptation to those impacts. One of the most important contributions of this review is the description of how climate change data is produced, analyzed, and hosted by different types of authors in different formats. The knowledge network in place in the Chesapeake Bay is complex and includes different stakeholders. Scientists still play an important and growing role in the collection of environmental data, but it is now a noticeable trend how scientists are increasingly diversifying the way in which their studies are communicated to the wider public and policy-makers. More online resources are becoming available, which may present a challenge for local and municipal authorities to identify legitimate and useful sources of science-based information. Taken together, it is possible to say that the web of knowledge on climate change impacts and adaptation is more complex and diverse than it was in 2007, when the Maryland Commission on Climate Change was established. Therefore, reviews like this one are important in assessing the information landscape in a way that may empower stakeholders and decision-makers at all levels of governance to find the right type of information and make informed decisions that support resilience-building and adaptation.

\section{Conclusions}

Anthropogenic climate change is already affecting the livelihood of humans around the world by driving changes to the ocean and land ecosystems we depend on [2]. As such, governments at different levels (country, state, county, and municipality), academia, and civil society have shown greater interest in tracking the availability and effectiveness of climate change adaptation indicators. The systematic review presented in this article centers in the State of Maryland, USA, home of the Chesapeake Bay, and answered the questions (i) how are indicators of climate impacts measured and reported by different types of authors, document types, and geographic focus? (ii) what are the current approaches for measuring the most pressing climate impacts in Maryland and the Chesapeake Bay? Concerning how climate impacts are measured and reported, we found that most documents in our sample were authored by scientists, followed by state government, NGOs, national, county and municipal governments. The majority of documents were in report form, followed by academic journal articles and online resources. The geographic focus of documents was evenly split with some documents focusing on the State of Maryland and others on the Chesapeake Bay region. A smaller number of documents focused on regional, county, and municipal aspects of climate change adaptation.

We have presented a qualitative and quantitative analysis of the information landscape in this region and have highlighted the synergies that exist between authors researching and working in similar regions and on similar climate-related problems. For example, how scientists and county managers have shared interests in testing the effectiveness of stormwater management systems in the context of increasing precipitation in the 21st century. At the same time, we have highlighted on some areas where science can meet the needs of practitioners. For example, scientific research can play an important role in identifying shorelines vulnerable to SLR using advance technologies like satellite imagery. As such, the characterization of how quantitative data is produced and reported by different types of authors, document types, and geographic focus is intended to facilitate knowledge exchange between scientists, government, NGOs, and adaptation managers at the county and municipal level in ways that expedite the capacity of adaptation to climate change.

Concerning the current and emerging approaches for the measurement of climate impacts in Maryland and the Chesapeake Bay, we found that most indicators and datasets within our sample are related to SLR and coastal and river flooding. This overwhelming attention to SLR and flooding was not a surprise, given that Maryland's 4000-miles of shoreline, and its network of tidal rivers and the Atlantic coast, makes the state particularly susceptible to flooding and erosion brought on by tides, 
storms, and increasingly SLR. Our review presented some recommendations on areas where emerging scientific research overlaps with government's interest and communities' needs. Specifically, we believe that improving real-time data collection of SLR, identifying vulnerable areas, and enabling the state to acquire and/or maintain endangered coastal ecosystems will advance the science and the adaptation to SLR in the region. Changes in precipitation patterns are certain to happen; however, improving the accuracy of precipitation projections is of utmost importance for those concern about agricultural pollution through runoff into the Bay and the saturation of stormwater management systems in growing urban areas. Furthermore, authorities and the general public are concerned about the efficacy of adaptation measures (e.g., agricultural BMPs, green infrastructure, and socio-economic policies). As such, we identified a growing trend in participatory research being employed as an approach to engage a wider range of stakeholders and solicit information that may lead to better adaptive and collaborative management. These approaches are conducive to the co-creation of knowledge and may achieve the interactions needed between scientists, government, and civil society that may enhance the adaptive capacity to climate change [96]. In this respect, we believe that the climate change adaptation community may benefit from knowledge in sustainability science, which overlap in their efforts to understand co-creation of knowledge through transdisciplinary methods [97,98]. Moreover, a trend on perception-based research suggests that climate change adaptation performance may be measured, to some extent, by soliciting perceptions of stakeholders about the process and outcomes of collaborative decision-making [99].

Considering the challenges presented by climate change and the deficiencies of adaptation systems, it is important to develop frameworks and tools that can support climate adaption at different levels of governance. Creating holistic indicators of climate change adaptation is still in early stages of development. Based on our review, we can say that improving the data collection capabilities of environmental changes at different geographic scales and providing collaborative opportunities for stakeholders will likely empower decision-makers and managers with important information. Moreover, social indicators like social capital, stakeholder engagement, and perceptions of risk and awareness are essential for adaptation development and implementation but have not yet evolved into measurable indicators. Even though this review is focused on Maryland and the Chesapeake Bay, we believe these insights can be extend to other coastal areas around the planet that share similar climate-related risks as well as management challenges. Overall, climate adaptation requires the participation of stakeholders and the sharing of information at all geographic and governance levels. This means that experts and practitioners can standardize their engagement with vulnerable local communities and that local communities can increase their exposure to scientific knowledge. It remains a considerable challenge to measure the extent to which scientific knowledge is integrated into local knowledge in a way that translates to effective adaptation management. Nonetheless, we believe that reviews like ours may help stakeholders better understand the complex information network of climate change impacts and adaptation, which in turn may help them navigate it.

Supplementary Materials: The following are available online at http://www.mdpi.com/2225-1154/8/4/58/s1, Document S1: Inclusion Criteria, Document S2: Coding Schema.

Author Contributions: Conceptualization, data collection, formal analysis, and writing done by J.D.T. and B.N.; project administration and visualization, J.D.T. All authors have read and agreed to the published version of the manuscript.

Funding: Jose D. Teodoro received support from Maryland Sea Grant under award NA18OAR4170070 R/CL-2 from the National Oceanic and Atmospheric Administration, U.S. Department of Commerce.

Acknowledgments: We would like to extend our gratitude to Melissa Kenney and Kate McClure for providing guidance and insight throughout the development of this work.

Conflicts of Interest: The authors declare no conflict of interest. The funders had no role in the design of the study; in the collection, analyses, or interpretation of data; in the writing of the manuscript, or in the decision to publish the results. 


\section{References}

1. Hayhoe, K.; Wuebbles, D.J.; Easterling, D.R.; Fahey, D.W.; Doherty, S.; Kossin, J.; Sweet, W.; Vose, R.; Wehner, M. Our Changing Climate. In Impacts, Risks, and Adaptation in the United States: Fourth National Climate Assessment, Volume II; Reidmiller, D.R., Avery, C.W., Easterling, D.R., Kunkel, K.E., Lewis, K.L.M., Maycock, T.K., Stewart, B.C., Eds.; National Oceanic and Atmospheric Administration: Washington, DC, USA, 2018.

2. Hoegh-Guldberg, O.; Jacob, D.; Taylor, M.; Bindi, M.; Brown, S.; Camilloni, I.; Diedhiou, A.; Djalante, R.; Ebi, K.; Engelbrecht, F. Impacts of $1.5^{\circ} \mathrm{C}$ Global Warming on Natural and Human Systems; Intergovernmental Panel on Climate Change: Geneva, Switzerland, 2018.

3. Dannevig, H.; Rauken, T.; Hovelsrud, G. Implementing adaptation to climate change at the local level. Local Environ. 2012, 17, 597-611. [CrossRef]

4. Epanchin-Niell, R.; Kousky, C.; Thompson, A.; Walls, M. Threatened protection: Sea level rise and coastal protected lands of the eastern United States. Ocean Coast. Manag. 2017, 137, 118-130. [CrossRef]

5. Martinich, J.; DeAngelo, B.J.; Diaz, D.; Ekwurzel, B.; Franco, G.; Frisch, C.; McFarland, J.; O’Neill, B. Reducing Risks Through Emissions Mitigation. In Impacts, Risks, and Adaptation in the United States: Fourth National Climate Assessment, Volume II; Reidmiller, D.R., Avery, C.W., Easterling, D.R., Kunkel, K.E., Lewis, K.L.M., Maycock, T.K., Stewart, B.C., Eds.; U.S. Global Change Research Program: Washington, DC, USA, 2018; pp. 1346-1386.

6. Cutter, S.L.; Ahearn, J.A.; Amadei, B.; Crawford, P.; Eide, E.A.; Galloway, G.E.; Goodchild, M.F.; Kunreuther, H.C.; Li-Vollmer, M.; Schoch-Spana, M.; et al. Disaster Resilience: A National Imperative. Environ. Sci. Policy Sustain. Dev. 2013, 55, 25-29. [CrossRef]

7. Mandryk, M.; Reidsma, P.; Kartikasari, K.; van Ittersum, M.; Arts, B. Institutional constraints for adaptive capacity to climate change in Flevoland's agriculture. Environ. Sci. Policy 2015, 48, 147-162. [CrossRef]

8. Morrison, T.H.; Adger, W.N.; Brown, K.; Lemos, M.C.; Huitema, D.; Hughes, T.P. Mitigation and adaptation in polycentric systems: Sources of power in the pursuit of collective goals. Wiley Interdiscip. Rev. Clim. Chang. 2017, 8, e479. [CrossRef]

9. Glaas, E.; Jonsson, A.; Hjerpe, M.; Andersson-Sköld, Y. Managing climate change vulnerabilities: Formal institutions and knowledge use as determinants of adaptive capacity at the local level in Sweden. Local Environ. 2010, 15, 525-539. [CrossRef]

10. Vogt, N.; Pinedo-Vasquez, M.; Brondízio, E.S.; Rabelo, F.G.; Fernandes, K.; Almeida, O.; Riveiro, S.; Deadman, P.J.; Dou, Y. Local ecological knowledge and incremental adaptation to changing flood patterns in the Amazon delta. Sustain. Sci. 2016, 11, 611-623. [CrossRef]

11. Crona, B.; Bodin, Ö. Power asymmetries in small-scale fisheries: A barrier to governance transformability? Ecol. Soc. 2010, 15, 32. [CrossRef]

12. Chesapeake Bay Program. Climate Resiliency Outcomes Management Strategy; Chesapeake Bay Program: Annapolis, MD, USA, 2015.

13. Hileman, J.; Lubell, M. The network structure of multilevel water resources governance in Central America. Ecol. Soc. 2018, 23, art48. [CrossRef]

14. MCCC Maryland Commission on Climate Change. 2016 Annual Report; MCCC Maryland Commission on Climate Change: Baltimore, MD, USA, 2016.

15. Burkett, V.R.; Davidson, M.A. (Eds.) Coastal Impacts, Adaptation and Vulnerability: A Technical Input to the 2012 National Climate Assessment. Cooperative Report to the 2013 National Climate Assessment; Island Press: Washington, DC, USA, 2012; ISBN 1610914333.

16. Pyke, C.R.; Najjar, R.G.; Adams, M.B.; Breitburg, D.; Kemp, M.; Hershner, C.; Howarth, R.; Mulholland, M.; Paolisso, M.; Secor, D.; et al. Climate Change and the Chesapeake Bay: State-of-the-Science Review and Recommendations; Chesapeake Bay Program Science and Technical Advisory Committee (STAC): Annapolis, MD, USA, 2008.

17. Ambrette, B. Prioritizing Local Climate Adaptation through Regional Collaboration on Maryland's Eastern Shore; Eastern Shore Land Conservancy: Easton, MD, USA, 2017.

18. Schulte, D.M.; Dridge, K.M.; Hudgins, M.H. Climate Change and the Evolution and Fate of the Tangier Islands of Chesapeake Bay, USA. Sci. Rep. 2015, 5, 17890. [CrossRef] 
19. Najjar, R.G.; Pyke, C.R.; Adams, M.B.; Breitburg, D.; Hershner, C.; Kemp, M.; Howarth, R.; Mulholland, M.R.; Paolisso, M.; Secor, D.; et al. Potential climate-change impacts on the Chesapeake Bay. Estuar. Coast. Shelf Sci. 2009, 86, 1-20. [CrossRef]

20. Sweet, W.V.; Dusek, G.; Obeysekera, J.; Marra, J.J. Patterns and Projections of High Tide Flooding Along the U.S. Coastline Using a Common Impact Threshold; National Oceanic and Atmospheric Administration: Silver Spring, MD, USA, 2018.

21. Akerlof, K.L.; Delamater, P.L.; Boules, C.R.; Upperman, C.R.; Mitchell, C.S.; Akerlof, K.L.; Delamater, P.L.; Boules, C.R.; Upperman, C.R.; Mitchell, C.S. Vulnerable Populations Perceive Their Health as at Risk from Climate Change. Int. J. Environ. Res. Public Health 2015, 12, 15419-15433. [CrossRef] [PubMed]

22. Godin, K.; Stapleton, J.; Kirkpatrick, S.I.; Hanning, R.M.; Leatherdale, S.T. Applying systematic review search methods to the grey literature: A case study examining guidelines for school-based breakfast programs in Canada. Syst. Rev. 2015, 4, 138. [CrossRef] [PubMed]

23. Saldaña, J. The Coding Manual for Qualitative Researchers; SAGE Publications Ltd.: London, UK, 2015; ISBN 1473943590.

24. Richards, L. Handling Qualitative Data: A Practical Guide; Sage: New York, NY, USA, 2005.

25. Petticrew, M.; Roberts, H. Systematic Reviews in the Social Sciences: A practical Guide; Blackwell Publishing Ltd.: Malden, MA, USA, 2008; ISBN 1405150149.

26. Bierbaum, R.; Smith, J.B.; Lee, A.; Blair, M.; Carter, L.; Chapin, F.S.; Fleming, P.; Ruffo, S.; Stults, M.; McNeeley, S.; et al. A comprehensive review of climate adaptation in the United States: More than before, but less than needed. Mitig. Adapt. Strateg. Glob. Chang. 2013, 18, 361-406. [CrossRef]

27. Boesch, D.F.; Atkinson, L.P.; Boicourt, W.C.; Boon, J.D.; Cahoon, D.R. Updating Maryland's Sea-level Rise Projections. Special Report of the Scientific and Technical Working Group to the Maryland Climate Change Commission; University of Maryland Center for Environmental Science: Cambridge, MD, USA, 2013.

28. Boesch, D.F.; Boicourt, W.C.; Cullather, R.I.; Ezer, T.; Galloway, G.E., Jr.; Johnson, Z.P.; Kilbourne, K.H.; Kirwan, M.L.; Kopp, R.E.; Land, S.; et al. Sea-level rise Projections for Maryland 2018; NASA: Cambridge, MD, USA, 2018.

29. Hoss, F.; Fischbach, J.; Molina-Perez, E. Effectiveness of Best Management Practices for Stormwater Treatment as a Function of Runoff Volume. J. Water Resour. Plan. Manag. 2016, 142, 05016009. [CrossRef]

30. Renkenberger, J.; Montas, H.; Leisnham, P.T.; Chanse, V.; Shirmohammadi, A.; Sadeghi, A.; Brubaker, K.; Rockler, A.; Hutson, T.; Lansing, D. Effectiveness of Best Management Practices with Changing Climate in a Maryland Watershed. Trans. ASABE 2017, 60, 769-782. [CrossRef]

31. Harris, C.R.; McElfish, J. Green Infrastructure for Chesapeake Stormwater Management: Legal Tools for Climate Resilient Siting; HeinOnline: Washington, DC, USA, 2017.

32. Glick, P.; Staudt, A.; Nunley, B. Sea-Level Rise and Coastal Habitats of the Chesapeake Bay: A Summary; HeinOnline: Reston, MD, USA, 2008.

33. Glandon, H.L.; Kilbourne, K.H.; Schijf, J.; Miller, T.J. Counteractive effects of increased temperature and pCO2 on the thickness and chemistry of the carapace of juvenile blue crab, Callinectes sapidus, from the Patuxent River, Chesapeake Bay. J. Exp. Mar. Bio. Ecol. 2018, 498, 39-45. [CrossRef]

34. Glaspie, C.N.; Longmire, K.; Seitz, R.D. Acidification alters predator-prey interactions of blue crab Callinectes sapidus and soft-shell clam Mya arenaria. J. Exp. Mar. Bio. Ecol. 2017, 489, 58-65. [CrossRef]

35. Glaspie, C.; Seitz, R.; Ogburn, M.; Dungan, C.; Hines, A. Impacts of habitat, predators, recruitment, and disease on soft-shell clams Mya arenaria and stout razor clams Tagelus plebeius in Chesapeake Bay. Mar. Ecol. Prog. Ser. 2018, 603, 117-133. [CrossRef]

36. Talbot County. Hazard Mitigation E Community Resilience Plan; Talbot County: Easton, MD, USA, 2017.

37. Calvert County. Calvert County Maryland Flood Mitigation Plan; Calvert County: Prince Frederick, MD, USA, 2017.

38. Anne Arundel County. Sea Level Rise Strategic Plan Anne Arundel County Phase 1 Report: Vulnerability Assessment; Anne Arundel County: Annapolis, MD, USA, 2010.

39. Somerset County. Somerset County, Maryland Rising Sea Level Guidance; Somerset County: Princess Anne, USA, MD, 2008.

40. Montgomery County. Montgomery County, Maryland Climate Protection Plan; Montgomery County: Rockville, MD, USA, 2009. 
41. Renkenberger, J.; Montas, H.; Leisnham, P.T.; Chanse, V.; Shirmohammadi, A.; Sadeghi, A.; Brubaker, K.; Rockler, A.; Hutson, T.; Lansing, D. Climate change impact on critical source area identification in a Maryland watershed. Trans. ASABE 2016, 59, 1803-1819.

42. Kent County. Hazard Mitigation Plan 2014; Kent County: Chestertown, MD, USA, 2014.

43. Harris, T.; Brownlee, D. Breezy Point and Neeld Estate Flood Mitigation Plan; Calvert Country: Prince Frederick, MD, USA, 2016.

44. Spanger-Siegfried, E.; Dahl, K.; Calds, A.; Udvardy, S.; Cleetus, R.; Worth, P.; Hammer, N.H. When Rising Seas Hit Home; Union of Concerned Scientists: Cambridge, MA, USA, 2017.

45. Johnson, Z.P. Climate Change and Coast Smart Construction: Infrastructure Siting and Design Guidelines. Special Report of the Adaptation Response Working Group of the Maryland Commission on Climate Change; Maryland Department of Natural Resources: Annapolis, MD, USA, 2014.

46. ESLC Eastern Shore Land Conservancy. Climate Change and Sea Level Rise Adaptation Report Kent County, Maryland; ESLC Eastern Shore Land Conservancy: Chestertown, MD, USA, 2016.

47. Worcester County. 2014 Worcester County Hazard Mitigation Plan Update; Worcester County: Snow Hill, MD, USA, 2014.

48. Somerset County. Somerset County, Md 2015 Floodplain Map; Somerset County: Princess Anne, MD, 2015.

49. Cross, M.; Rowland, E.; Long, D.; Tully, E.; Dunning, K. 14 Solutions to Problems Climate Change Poses for Conservation; WCS: Washington, DC, USA, 2016.

50. Glick, P.; Clough, J.; Nunley, B. Warren Pinnacle Consulting Inc. Sea-Level Rise and Coastal Habitats in the Chesapeake Bay Region; National Wildlife Federation: Reston, MD, USA, 2008.

51. Kane, A. Managing Coastal Watersheds to Address Climate Change: Vulnerability Assessment and Adaptation Options for the Middle Patuxent Subwatershed of the Chesapeake Bay; National Wildlife Federation: Reston, MD, USA, 2013.

52. Dunn, J.; Stamey, B. Climate Change Solutions; The Conservation Fund: Arlington, VA, USA, 2010.

53. Anderson, M.G.; Barnett, A. Resilient Coastal Sites for Conservation in the Northeast and Mid-Atlantic US; Rutgers University Libraries: Washington, DC, USA, 2017.

54. Maryland Sea Grant. COME HIGH WATER Sea Level Rise and Chesapeake Bay; Maryland Sea Grant: College Park, MD, USA, 2015.

55. World Bank. Managing Coasts with Natural Solutions: Guidelines for Measuring and Valuing the Coastal Protection Services of Mangroves and Coral Reefs; World Bank: Washington, DC, USA, 2016.

56. Kang, H.; Sridhar, V. Assessment of Future Drought Conditions in the Chesapeake Bay Watershed. JAWRA J. Am. Water Resour. Assoc. 2018, 54, 160-183. [CrossRef]

57. Hawkins, T.W. Simulating the Impacts of Projected Climate Change on Streamflow Hydrology for the Chesapeake Bay Watershed. Ann. Assoc. Am. Geogr. 2015, 105, 627-648. [CrossRef]

58. Wagena, M.B.; Collick, A.S.; Ross, A.C.; Najjar, R.G.; Rau, B.; Sommerlot, A.R.; Fuka, D.R.; Kleinman, P.J.A.; Easton, Z.M. Impact of climate change and climate anomalies on hydrologic and biogeochemical processes in an agricultural catchment of the Chesapeake Bay watershed, USA. Sci. Total Environ. 2018, 637-638, 1443-1454. [CrossRef] [PubMed]

59. Segura, C.; Sun, G.; McNulty, S.; Zhang, Y. Potential impacts of climate change on soil erosion vulnerability across the conterminous United States. J. Soil Water Conserv. 2014, 69, 171-181. [CrossRef]

60. Williamson, S.; Horin, C.; Ruth, M.; Weston, R.F.; Ross, K.; Irani, D. Climate Change Impacts on Maryland and the Cost of Inaction; College Park University of Maryland: Annapolis, MD, USA, 2008.

61. Montgomery County. Montgomery County Hazard Mitigation Plan 2013; Montgomery County: Rockville, MD, USA, 2013.

62. Prince George's County. Prince George's County and the City of Laurel Maryland Hazard Mitigation Plan; Prince George's County: Upper Marlboro, MD, USA, 2010.

63. Soneja, S.; Jiang, C.; Fisher, J.; Upperman, C.R.; Mitchell, C.; Sapkota, A. Exposure to extreme heat and precipitation events associated with increased risk of hospitalization for asthma in Maryland, U.S.A. Environ. Heal. 2016, 15, 57. [CrossRef]

64. Wagena, M.B.; Easton, Z.M. Agricultural conservation practices can help mitigate the impact of climate change. Sci. Total Environ. 2018, 635, 132-143. [CrossRef] 
65. Liu, A.; Soneja, S.I.; Jiang, C.; Huang, C.; Kerns, T.; Beck, K.; Mitchell, C.; Sapkota, A. Frequency of extreme weather events and increased risk of motor vehicle collision in Maryland. Sci. Total Environ. 2017, 580, 550-555. [CrossRef]

66. Soneja, S.; Jiang, C.; Romeo Upperman, C.; Murtugudde, R.; Mitchell, C.S.; Blythe, D.; Sapkota, A.R.; Sapkota, A. Extreme precipitation events and increased risk of campylobacteriosis in Maryland, U.S.A. Environ. Res. 2016, 149, 216-221. [CrossRef]

67. Curriero, F.C.; Patz, J.A.; Rose, J.B.; Lele, S. The Association Between Extreme Precipitation and Waterborne Disease Outbreaks in the United States, 1948-1994. Am. J. Public Health 2001, 91, 1194-1199. [CrossRef]

68. Urquhart, E.A.; Zaitchik, B.F.; Waugh, D.W.; Guikema, S.D.; Del Castillo, C.E. Uncertainty in Model Predictions of Vibrio vulnificus Response to Climate Variability and Change: A Chesapeake Bay Case Study. PLoS ONE 2014, 9, e98256. [CrossRef]

69. Chesapeake Bay Program. Chesapeake Bay Watershed Agreement; Chesapeake Bay Program: Annapolis, MD, USA, 2014.

70. Li, M.; Lee, Y.J.; Testa, J.M.; Li, Y.; Ni, W.; Kemp, W.M.; Di Toro, D.M. What drives interannual variability of hypoxia in Chesapeake Bay: Climate forcing versus nutrient loading? Geophys. Res. Lett. 2016, 43, 2127-2134. [CrossRef]

71. Du, J.; Shen, J.; Park, K.; Wang, Y.P.; Yu, X. Worsened physical condition due to climate change contributes to the increasing hypoxia in Chesapeake Bay. Sci. Total Environ. 2018, 630, 707-717. [CrossRef] [PubMed]

72. Boesch, D.F. Global Warming and Coastal Dead Zones; National Wetlands Newsletter: Washington, DC, USA, 2008.

73. Harding, L.W.; Gallegos, C.L.; Perry, E.S.; Miller, W.D.; Adolf, J.E.; Mallonee, M.E.; Paerl, H.W. Long-Term Trends of Nutrients and Phytoplankton in Chesapeake Bay. Estuaries Coasts 2016, 39, 664-681. [CrossRef]

74. Scavia, D.; Bertani, I.; Obenour, D.R.; Turner, R.E.; Forrest, D.R.; Katin, A. Ensemble modeling informs hypoxia management in the northern Gulf of Mexico. Proc. Natl. Acad. Sci. USA 2017, 114, 8823-8828. [CrossRef]

75. Hines, A.H.; Johnson, E.G.; Darnell, M.Z.; Rittschof, D.; Miller, T.J.; Bauer, L.J.; Rodgers, P.; Aguilar., R. Predicting Effects of Climate Change on Blue Crabs in Chesapeake Bay. In Biology and Management of Exploited Crab Populations under Climate Change; Kruse, G.H., Eckert, G.L., Foy, R.J., Lipcius, R.N., Sainte-Marie, B., Stram, D.L., Woodby, D., Eds.; Alaska Sea Grant, University of Alaska Fairbanks: Fairbanks, AK, USA, 2010.

76. Pierson, J.J.; Kimmel, D.G.; Roman, M.R. Temperature Impacts on Eurytemora carolleeae Size and Vital Rates in the Upper Chesapeake Bay in Winter. Estuaries Coasts 2016, 39, 1122-1132. [CrossRef]

77. IAN Integration and Application Network. Chesapeake Bay Report Card 2017; IAN Integration and Application Network: College Park, MD, USA, 2017.

78. Pintér, L.; Hardi, P.; Martinuzzi, A.; Hall, J. Bellagio STAMP: Principles for sustainability assessment and measurement. Ecol. Indic. 2011, 17, 20-28. [CrossRef]

79. Considine, C.; Steinhilber, E. Collaborative Strategies for Sea Level Rise Adaptation in Hampton Roads, Virginia. J. Green Build. 2018, 13, 193-214. [CrossRef]

80. Kenney, M.A.; Janetos, A.C.; Lough, G.C. Building an integrated U.S. National Climate Indicators System. Clim. Change 2016, 135, 85-96. [CrossRef]

81. Kenney, M.A.; Dukes, J.S.; Lips, K.R.; Hellmann, J.J. Engagement 2.0: Increasing our collective impact. Front. Ecol. Environ. 2016, 14, 403. [CrossRef]

82. Johnson, Z.P. Sea Level Rise: Maryland's Model for Adapting to Climate Change. In A Sustainable Chesapeake: Better Models for Conservation; Burke, D.G., Dunn, J.E., Eds.; Conservation Fund: Annapolis, MD, USA, 2010; pp. 3-12.

83. Brock, R.; Beavers, R. Climate Change and Sea Level Rise: What can Marine Protected Areas Do to Lessen Impacts? National Marine Protected Areas Center: Silver Spring, MD, USA, 2015.

84. Du, J.; Shen, J.; Bilkovic, D.M.; Hershner, C.H.; Sisson, M. A Numerical Modeling Approach to Predict the Effect of a Storm Surge Barrier on Hydrodynamics and Long-Term Transport Processes in a Partially Mixed Estuary. Estuaries Coasts 2017, 40, 387-403. [CrossRef]

85. Grannis, J.; Hoverter, S.; Bennett, A.; Deas, M.; DeWeese, J. Policy Considerations for the Maryland Commission on Climate Change; GCC: Washington, DC, USA, 2017.

86. City of Baltimore. Chapter 5: Strategies and Actions; City of Baltimore: Baltimore, MD, USA, 2015. 
87. Gasper, R.R.; Selman, M.; Ruth, M. Climate co-benefits of water quality trading in the chesapeake bay watershed. Water Policy 2012, 14, 758-765. [CrossRef]

88. Muter, B.A.; Gore, M.L.; Riley, S.J. Social Contagion of Risk Perceptions in Environmental Management Networks. Risk Anal. 2013, 33, 1489-1499. [CrossRef] [PubMed]

89. Prell, C.; Reed, M.S.; Racin, L.; Hubacek, K. Competing structure, competing views: The role of formal and informal social structures in sahping stakeholder perceptions. Ecol. Soc. 2010, 15, 34. [CrossRef]

90. Gore, M.L.; Knuth, B.A.; Curtis, P.D.; Shanahan, J.E. Stakeholder Perceptions of Risk Associated with Human-Black Bear Conflicts in New York's Adirondack Park Campgrounds: Implications for Theory and Practice. BioOne 2009. [CrossRef]

91. Akerlof, K.; Rowan, K.; La Porte, T.; Batten, B.; Ernst, H.; Sklarew, D. Risky business: Engaging the public on sea level rise and inundation. Environ. Sci. Policy 2016, 66, 314-323. [CrossRef]

92. Akerlof, K.; Moser, F.; Dindinger, J.; Rowan, K. Perceptions of Community Resilience: A Maryland Community Pilot Study; George Mason University Foundation: Fairfax, VA, USA, 2016.

93. Leenders, R.A.J. Modeling social influence through network autocorrelation: Constructing the weight matrix. Soc. Networks 2002, 24, 21-47. [CrossRef]

94. Kahan, D.M. Climate-science communication and the measurement problem. Polit. Psychol. 2015, 36, 1-43. [CrossRef]

95. Hondula, D.M.; Balling, R.C.; Vanos, J.K.; Georgescu, M. Rising Temperatures, Human Health, and the Role of Adaptation. Curr. Clim. Chang. Reports 2015, 1, 144-154. [CrossRef]

96. Lemos, M.C.; Kirchhoff, C.J.; Ramprasad, V. Narrowing the climate information usability gap. Nat. Clim. Chang. 2012, 2, 789-794. [CrossRef]

97. Mauser, W.; Klepper, G.; Rice, M.; Schmalzbauer, B.S.; Hackmann, H.; Moore, H. Transdisciplinary global change research: The co-creation of knowledge for sustainability. Curr. Opin. Environ. Sustain. 2013, 5, 420-431. [CrossRef]

98. Brandt, P.; Ernst, A.; Gralla, F.; Luederitz, C.; Lang, D.J.; Newig, J.; Reinert, F.; Abson, D.J.; von Wehrden, H. A review of transdisciplinary research in sustainability science. Ecol. Econ. 2013, 92, 1-15. [CrossRef]

99. Plummer, R.; Dzyundzyak, A.; Baird, J.; Bodin, Ö.; Armitage, D.; Schultz, L. How do environmental governance processes shape evaluation of outcomes by stakeholders? A causal pathways approach. PLOS ONE 2017, 12, e0185375. 